\title{
Analysis of energy poverty intensity from the perspective of the regional administration: empirical evidence from households in Southern Europe
}

\author{
Sabina Scarpellini* \\ CIRCE - Centre for Research of Energy Resources and Consumption. University of \\ Zaragoza - Department of Management-E-mail: sabina@unizar.es \\ Pilar Rivera-Torres \\ Department of Marketing - University of Zaragoza E-mail: privera@unizar.es \\ Inés Suárez-Perales \\ CIRCE - Centre for Research into Energy Resources and Consumption. University of \\ Zaragoza E-mail: isuarez@unizar.es \\ Alfonso Aranda-Usón \\ Department of Management - University of Zaragoza E-mail: alaranda@unizar.es
}

\begin{abstract}
The current economic situation has increased the number of households in Europe experiencing restrictions and/or limitations of affordability of energy services, demonstrating the urgent need to intervene in those extreme cases in which households suffer the daily consequences of what is internationally defined as energy poverty. In such a context, this paper presents the results obtained in a case study characterising a sample of 615 households with demonstrated energy poverty in the region of Aragón (Spain). In parallel, the intensity of energy poverty in the studied cases is examined by measuring the percentage of energy expenditures with respect to income in the households that suffer it, and a descriptive analysis of the main determinants of energy poverty in the homes studied is presented as well as the policy implication at regional level.
\end{abstract}

\section{Key word}

Energy poverty - Regional Government - Empirical evidence - Correlations - Social Services 


\section{Introduction}

The economic situation in Europe has increased the number of households with unexpected economic difficulties and situations of debt and insolvency. Among other negative consequences, the low income and the consequent household decapitalisation are significant limitations to accessing energy resources necessary for the home.

In many cases, housing is in fact one of the elements that Europeans use to reduce household spending in times of recession, causing an increase of extreme cases in which some suffer the daily consequences of what is internationally defined as energy or fuel poverty. Energy poverty is here understood as the economic inability of the home to meet its domestic energy needs, increasing as energy expenditures and their relative significance in relation to household income also rise

Spain has also been affected by this problem, and action has been taken by different institutions mainly to assess the problem at the local, regional, and national level and to define which actions ought to be taken and measures adopted. To do so, the Public Administration must identify the households that are most vulnerable to the problem and their main features to take concrete steps that are preventive in nature and suitable for every type of household. These steps would also be taken to avoid situations of consumer vulnerability that may lead to severe energy poverty in all the European countries, as Spain, located in the south of the European Union (EU), even though they have more favourable weather conditions than in northern Europe. Substantial differences among EU member states have in fact been detected, with Southern and Eastern European countries generally reporting a higher incidence of energy poverty (Tirado-Herrero and Bousarovsky 2014), and the highest incidences of fuel poverty in southern Europe include Portugal, Spain, Greece and Italy (Healy and Clinch 2002b). 

deterioration of living conditions and socio-economic development for society in general. For this reason, the need to protect citizens from energy vulnerability (Bouzarovski 2012) and to prevent social exclusion by ensuring basic access to energy at reasonable and stable prices (CESE, 2013) has been considered in all Europe. This consideration is acknowledged, in fact, in the third energy package of the year 2009 (Rab et al. 2011), in which Member States of the European Union should take appropriate steps to protect these clients.

Nevertheless, the EU approach has led to some fragmentation in member States' actions concerning energy poverty, not only in relation to the definition of energy poverty or vulnerable consumers but also regarding measurement and the definition of preventive or palliative measures implemented in each country. In most member countries, market competition is not the main factor affecting the significant components of individuals' final energy bill but rather numerous taxes, levies, supports for energy diversification and security, etc. that depend on national energy policy.

In this context, it is important to have primary source material to provide a complete picture of the energy poverty phenomenon in each country, in line with the approach proposed by Howden-Chapman, et al. (2012) and by Brunner et al. (2012). These authors advocate for a holistic approach to the daily energy practices of households on low incomes and/or suffering from fuel poverty that is needed at national and local level.

The paper is focused on this goal and it is divided into five sections. After the introduction, the second section presents a background of literature on energy poverty in terms of its definition and operationalization. The third section provides an account of the empirical work conducted, including the sample, variables, and methodology used for 
analysis. The fourth section describes the main results, and in the last section, the main research conclusions are presented.

\section{Background}

In recent years, the definition of the concept of energy poverty has been a recurrent issue that has reached a certain level of agreement about issues of affordability and unmet needs of domestic energy services. The advisability of using Boardman's (1991) initial proposal at the European level has been debated, with the author stating that the proportion of household income spent on energy services in a household is the main indicator of the scope of energy poverty.

Based on this fundamental contribution, the use of $10 \%$ of income to sufficiently meet energy needs (Boardman 1991) as an index to detect households in energy poverty was introduced in the debate (Lidell et. al. 2012), in addition to other needs regarding the analysis of comfort in a home with indoor temperatures ranging between $18{ }^{\circ} \mathrm{C}$ and $21{ }^{\circ} \mathrm{C}$ (see BERR report 2001). Other authors, such as Hills (2012), the International Energy Agency (IEA 2011), Tirado-Herrero et al. (2012), and Thomson and Snell (2013), introduced concepts such as "cold home," "energy debt," and "relative" perspectives into the definition of "energy poverty" (Grévisse and Brynart 2011). Li et al. (2014) provide a summary of the related concept as used in the literature and foremost a principal distinction regards access versus affordability. In general terms energy poverty is frequently used regarding the inability to obtain or maintain service, and fuel poverty means a temporal variability of domestic energy deprivation.

Bouzarovski et al. (2014) pointed out that the factors that contribute to the rise of domestic energy deprivation can be captured under the concept of 'energy vulnerability' defined, simply, as the propensity of an individual to become incapable of securing a 
materially and socially needed level of energy service in the home, thinking brings to the fore issues of resilience and precariousness.

These different concepts highlight that the term's definition is not univocally applied and outside the third world energy poverty is now generally considered to be relative, in line with Moore (2012). A relative conception of the phenomenon is therefore applied in this study, and a household is considered to suffer energy poverty if its dwellers are unable to pay for energy services sufficient to satisfy domestic needs, once such economic necessity has been "accredited" by the Social Services that attend/support the home, whether regional/local or other competent authorities depended on for this purpose.

Despite the fact that the accreditation of energy poverty may be restrictive and those households that suffer the consequences of this problem without being recipients of social aid may be excluded from the analysis, the application of this approach allows one to limit urgent situations to a territorial level to clearly define the problem determinants by tracing households in need according to their features, thus planning public and private interventions based on specific measurements.

Defining households in energy poverty on the basis of accreditation also responds to a holistic view of the problem that regards energy poverty as one of the indexes of relative poverty (Practical Action, 2013) in a context of the overall poverty that represents the problem according to a classification of society into two groups: those who are most disadvantaged, which could be called "poor" (in this case in "energy" terms) and the rest.

In Europe, the latter typically involves the intervention of social services or social action agencies. The implementation of this approach allows one to identify urgent situations using a broader criterion that goes beyond age or household member income (Boardman 2012). As Chaudhuri and Ravallion (1994) indicate, the most important studies 
in this field highlight the direct relationship between household income and level of poverty, both general and relative in order to define the solutions.

In Spain, Tirado-Herrero et al. (2014) estimates that, in 2012, 17\% Spanish households ( $12 \%$ in 2010) were subject to disproportionate domestic energy expenses (over $10 \%$ of their annual income). The 2012 percentage figure is equivalent to 7 million people affected by this condition (5 million in 2010) and 9\% of Spanish households (8\% in 2010) were unable to keep their home adequately warm during wintertime. In the same year, the percentage of households in Region of Aragon (in the Northeast of Spain) with domestic energy expenses over $10 \%$ of their annual income was higher than the Spanish average, while the percentage of households unable to keep their home adequately warm during wintertime was below the Spanish average throughout the series studied by Tirado-Herrero et al. (2014).

In Europe, different empirical studies that have been conducted using large sample sizes are not numerous, and the relationship between energy poverty, thermal comfort, and the consequences of living in inadequately heated housing (Healy and Clinch 2002) continues to be the subject of analysis with regard to defining specific actions to be undertaken. Even that, the most recent publications has yielded further clarity regarding the phenomenon experienced by households in Europe. Devaliere (2010) conducted a quantitative empirical study in France in 2010 that focused on 2 samples of 40 homes in 2 territories. Along similar lines, the empirical analysis of Santamouris et al. in Greece provided a large sample of households (598) and defined 2 types of situations derived from income level while furthering the characterisation of energy consumption in a time series. Similarly, the level of energy consumption in each household and its social impact have been extensively analysed by Roberts (2008) and Tirado-Herrero et al. (2014). 
However, some authors have identified the lack of uniformity among European and national statistical data as a limitation, as well as a shortage of data and a lack of surveys and specific methodology for measuring the phenomenon (Heindl, P. 2013).

When we look closely at the analysis of preventive or palliative proposals, Grévisse and Brynart (2011) provide a synthesis of the measures undertaken in the European Union, differentiating between the activities aimed at consumer protection and those designed to avoid disconnection of energy supply. The energy refurbishment of housing (EspadaNicolas et al, 2012 and Tirado-Herrero et al. 2012) has also been identified as a possible solution in Europe. Additionally, improvement in energy efficiency for community-based services (Practical Action, 2013), centralised energy generation (Santillan-Cabeza, 2011), and modification and relaxation of requirements to qualify for social tariff or reduced rates (Tirado-Herrero et al., 2014) have also been recurrent proposals.

It has to be taken into account that energy poverty policy (as social inclusion initiatives) and measures imply in fact a multiple governance levels because it can rarely be dealt with independently from other pressing issues at the local level due to its complementarities with other issues as energy efficiency or green technologies (European Commission 2013). European Regions are at least involved in this phenomenon.

Here lies the main reason for deciding to perform a deep analysis of energy poverty in an European region as a case study in Spain, from a suitable perspective for decisionmaking by the regional administration and proposing potential decisive and effective measures in a multi-level governance scheme: the Regional Government has in Spain administrative powers in planning and provide regional social services while local administrations, as municipalities (with more than 20,000 inhabitants) or counties, provide the primary social services in the territory. 
Table 1. Households receiving public aid to pay energy bills in Aragón form 2011 to 2015. (Source: by authors)

The need to assess the extent of this phenomenon and its main causes within the Region of Aragón lead in fact to the development of this research study (Table 2).

\section{TABLE 2}

Table 2. Evolution of aid amounts (euro) to pay energy bills in the Aragonese households from 2011 to 2015. (Source: by authors)

\section{Method}

The steps taken to achieve an understanding of the energy poverty phenomenon in this case study included: definition, measurement, monitoring, and recording and information, as proposed by Pachauri and Spreng (2011). Qualitative and quantitative analysis were considered necessary to obtain regional and disaggregated data regarding each household situation. 
Gathering information for the decision-making process represents a difficult task in general because most of the statistical data available regarding energy poverty in the EU are of the aggregate type (EU-SILC, 2003). Additionally, such data are obtained through nonspecific statistical databases (household surveys) or through empirical studies of partial or local samples (Morrison and Shortt 2008), which makes extrapolation to other climatic zones and different regional socio-economic environments more difficult.

The Region of Aragon has a population density of 28.2 inhabitants per km2 (IAEST 2013), more than $95 \%$ of the region of Aragon is included in the range of application of the law, and approximately $42 \%$ the Aragonese population lives in the countryside, where its population density is 3 times below the national average. Out of the 1,347,150 inhabitants of the region, 682,004 (IAE 2013) reside in the city of Zaragoza, which means that there are considerable differences within the territory between the rural areas and the main city. The region is entirely located in the continental north climate area of Spain (Blázquez et. al. 2013). This Region has not been excluded from the debate related to energy poverty due to the precarious economic situation of numerous families. The proposition of Regional Decree no. 466/13 related to energy poverty of November 2013 highlighted the need of analysing the rate of occurrence of this phenomenon and to define the opportune measures to alleviate and prevent the problem in households in the region.

\subsection{Design of the study}

As a first step of the study, a qualitative analysis of the regional energy poverty was carried out to achieve the principal objective of this work. A group of 65 experts and professionals representing 44 entities in Aragon answer to a semi-structured ("in depth") interview specially designed for this study, as they were considered "key informants" directly or indirectly related to the subject of the analysis. Furthermore, a total of 113 
representatives of different nature entities throughout the region collaborated (social services, NGOs end other organizations), whether in the preparation and gathering of the surveys, dissemination of the study and later in the collection of data and information ${ }^{1}$.

Data from secondary sources obtained from Social Services and NGOs actively working on this issue on a regional level were taken into account during the elaboration of the questionnaire for the empirical study. In fact, different several local administrations are responsible for providing basic social services and numerous NGOs in the region offer charities for assisting the most disadvantaged households. Neighbourhood and neighbour associations, foundations, and other non-profit entities offer a local support network to people under serious risk of exclusion $\mathrm{n}$ the territory as well.

The qualitative analysis indicated that households in the region could suffer different degrees of energy poverty depending on income level, the percentage of income devoted to energy expenditures, a series of other factors inherent to the building itself and its insulation systems, available facilities, and the habits of the household residents, on one hand, and the cost of energy supply (total amounts of energy bills), on the other. Ultimately, everything related to energy expenditures in the household was considered to be of interest when analysing its impact on the intensity of relative household poverty in terms of energy. Direct information about the state of the art was collected during this first phase of the analysis to better outline the study case and the empirical phase.

Thus, taking into account the objectives of the study and the results obtained through the qualitative analysis, the literature review and the secondary sources of information, the empirical phase was focused on homes in accredited energy poverty, i.e., those households

\footnotetext{
1 For more details about this phase of the study, please see: http://www.aragon.es/estaticos/GobiernoAragon/Departamentos/IndustriaInnovacion/StaticFiles/Pobreza\%20 Energetica.pdf page 22. (Accessed in June 2015).
} 
that receive emergency regional public or private aid for paying basic expenditures related to the house, in which aids for energy bills are included. These aids are subject to prior verification of such need and they are regulated by a number of specific regulations in each local authorities and private NGO.

Current emergency aid for these purposes includes special economic benefits aimed at addressing situations of need, as they arise, impacting individuals and families deprived of the essential means of livelihood. This complementary income, included in the budget of Spanish Ministry for Health, Social Services and Equality and delivered by local administrations ${ }^{2}$, aims at addressing the following needs, among others: a) the inability to continue using and enjoying a habitual residence, in particular, rent payments to maintain the right to use it; b) the lack of economic means to maintain conditions of habitability or to acquire basic utilities for the habitual residence; c) the aid granted to households in the region selected for study falls under the second category, focusing on the payment of some unpaid bills that could lead to situations of non-payment and service outages.

Once the population were defined, a questionnaire defining the scope of the phenomenon of energy poverty intensity in the region was designed. During the elaboration of the questionnaire, energy poverty indexes proposed by Mirza and Szirmai (2010) where analyzed. However, they were designed principally for rural areas of developing world where traditional biomass is important and relevant for our understanding of the complex phenomenon of energy poverty and the general conditions of households cannot be compared with the European needs. In terms of measurements and indicators that assess the

\footnotetext{
2 These public funds are regulated in the framework of a national agreement concerning the "Basic Social Services Local Authorities of the Spanish Ministry of Health, Social Services and Equality implemented by the Regional Governments, in this case by the Aragonese Institute for Social Services (IASS) and local authorities. At regional level, public aids are regulated by the Decree 48/1993 of 19 May and by Regional Law 4/1987 March 25 (BOA 59, May 28, 1993). Moreover, almost all Local authorities have issued a specific regulation to deliver emergency aid in its scope.
} 
phenomenon of energy poverty, Morrison and Shortt (2008) offer a clear analysis of the main variables chosen to represent the social component of fuel poverty. The development of indicators, an ongoing process that continues to require advances and efforts towards standardisation at the European level, was considered necessary for conducting empirical research studies. Home occupation was considered among the variables, as well as the average number of rooms per house. Additionally, installation quality and materials were taken into consideration in the design of the survey in these homes as noted by Rudge (2012).

A series of variables were selected to measure different aspects of the households and their residents, the characteristics of the residences and the facilities available in the home, consumption habits, etc.

When the questionnaire was fully drafted, it was sent to a team with multidisciplinary expertise who validated or proposed modifications to the questions. The received comments were introduced in the majority part of the cases and improved regarding the clarity of question formulation and how well the questions fit the goal of the study. A pre-test sent to a small sub-sample of households (through social workers in the case of the specific questionnaire) was carried out for obtaining the beta version of the questionnaire that was subsequently used in the online application. This step made it possible to enhance the design and layout features and to correct errors in the questions.

The first section of the questionnaire focused on personal data related to the respondent and included questions referring to education, age, gender, and the location of the housing. The second part of the questionnaire collected household data and included the number of residents, amount of income, housing conditions, and facilities. Expenditures related to electrical power, other forms of energy and transport, and certain habits of 
consumption were reflected in the third section. Finally, the respondent was asked whether he or she had received economic aid to cope with energy bill payments and the source from which this aid derived.

A population of 7,222 households receiving emergency aid to pay for the expenditures related to houses during 2013 was considered as households accredited by social services. Meanwhile, a large households that do not meet this criterion were excluded from analysis. The collection of quantitative data was conducted through social services and regional NGOs coordinated by the researchers involved in the study. Social workers (civil servants) and NGOs volunteers made home visits to households affected by energy poverty from which primary source data were gathered using both, paper questionnaires and on-line system, depending on the visitors. The data were collected checking the energy invoices of the families when the bills were available and the charges for energy consumption was taken into consideration including all the concepts as taxes or other cost components.

The questionnaires were administered from June to September 2014 resulting in a total of a sample 615 valid cases of households under conditions of energy poverty. Conducting the survey during the summer does not refute the results obtained, first, because energy expenditure data most sensitive to seasonality were requested for the entire year, and second, because increases in electricity expenditures in the summer may occur due to high temperatures in the region.

\subsection{Variables}

For the purpose of selecting appropriate study variables, features of the household (unit of analysis) and its members were analysed to describe the residences that the study 
participants live in and their energy consumption habits. Variables used in other studies of this type were also sought.

The variables chosen as indicators of the degree of household energy poverty in relation to "social" factors and thus to household characteristics (Morrison and Shortt 2008), were developed by the research team based on previous studies such as that conducted by Baker et al. (2003). Similarly, the definitions of approximate measurements of low income, unemployment level, and pensioner households (identified as high-risk factors) were based on insights provided by Cormack et al. (2004), Baker et al. (2003), and Rudge (2001).

Variables used to address home typology (Cormack et al., 2004) are those defined by Baker et al. (2003) and Rudge (2001), albeit for a different context. Meanwhile, we can refer to Cormack et al. (2003) and Baker et al. (2003) regarding single-parent households with young dependent children (also identified as a major risk for vulnerability) and for determining household characteristics in terms of heating systems as a risk of energy poverty. It is worth noting that the "income" indicator has been considered a proxy variable for quality of life and welfare in the household. Expenses related to lighting and power (household appliances), studied by authors such as Sovacool et al. (2012), were not itemized separately in the empirical study.

Taking into consideration the limitations of data availability, we do not consider the possibility of assigning different weights to the various indicators to generate a specific index, as described by Nussbaumer et al. (2012).

The variable of the houses location was considered in order to differentiate two subsamples, the rural or the urban area, taking into account that the extent of fuel poverty in areas with high proportions of small households (urban) can be overestimated and it can be 
underestimates in areas (rural) with high proportions of large households (Fahmy et al, 2011).

Thus, the following were considered to be indicators of energy poverty intensity: 1) the amount of household energy expenditures in absolute terms, and 2) the relative significance of energy expenditures in relation to household's income. The Table 3 shows the variables selected in our study.

\section{TABLE 3}

Table 3. Variables used in the study and descriptive analysis of principal results. (Source: by authors)

The first section of the questionnaire focused on personal data related to the respondent and included questions referring to education, age, gender, and the location of the housing. The second part of the questionnaire collected household data and included the number of residents, amount of income, housing conditions, and facilities. Expenditures related to electricity, other energies and transport, and certain habits of consumption were reflected in the third section. Finally, the respondent was asked whether he or she had received economic aid to cope with energy bill payments and the source from which this aid derived.

\subsection{Empirical Study}

After selecting the relevant variables, the information to be used in the analysis was organised. In this case, the information was compiled from an observational and nonexperimental perspective. After the exploratory data analysis, the main results obtained were 
contrasted with evidence resulting from the statistical analysis to depict the common characteristics of households living in energy poverty in the region studied.

A correlation analysis between the variables described and the two variables of household energy expenditures was performed for the observational phase of the study. Hence, in our analysis the assumptions of normality is not met (Muthen \& Satorra, 1995; Rivera \& Satorra, 2002; Satorra \& Bentler, 1994; Satorra, 2003), the general estimation method we use is MLR, Maximum Likelihood Robust, parameter estimates with standard errors that are robust to non-normality of the observed variables) (Muthen \& Muthen, 19982012). The software applications used were MPLUS 7.1 (Muthén and Muthén 1998-2012). The method of analysis was considered appropriate for an initial approximation of the relationship between energy costs in vulnerable households and the aforementioned variables.

\section{Results}

In order to approach the energy poverty phenomenon in this case stud, the principled characteristics of the 615 households sample affected by energy poverty in Aragón are described.

The situation of energy poverty of these households was certified by social services. This premise allow us to consider that both, the amount of household energy expenditures in absolute terms as this amount in relation to household income can be considered proxy indicators of energy poverty intensity.

These households have already accredited their incomes and their inability to meet the energy services. Thus, they will be more vulnerable as the energy costs increase, or when 
the relationship between their energy costs and their incomes increase. In this context, the main associations between the characteristics of the sample and the energy intensity indicators were analysed.

The main results of the analysis can be seen in Table 4 .

\section{Table 4}

Table 4. Main results. (Source: by authors)

One of the obtained results is that the main cause of energy poverty in the households studied is their low income level (the income derived from work or other types of public funds or compensation, as well as that coming from cash transfers) and, in particular, the unemployment that affects the vast majority of respondents. In fact, in more than $70 \%$ of the homes, all members were unemployed at the time of the completion of the questionnaire.

In more than $50 \%$ of the cases, more than 4 people reside in the household, with children living in more than $75 \%$ of these residences. With regard to household income, over $79 \%$ of the households are at the threshold of earning less than 9,000 euro a year in 2014. The percentage of households belonging to Spanish citizens is noteworthy because the $45.2 \%$ of the surveyed households are foreigners (immigrant population

With regard to the type of electrical supply contract stipulated in each household, it should be noted that, in more than $50 \%$ of the cases, the respondents say they do not clearly differentiate the electricity contract type in detail. Main contracts considered in the questionnaire for the electricity: Voluntary Price for the Small Consumer (VPSC), "Free market" tariff and "Social Tariff". This indicates a general lack of knowledge and information on rates and the possible contracts available in the Spanish market. In addition, 
it is noteworthy that most respondents do not know in detail the power usage rates for which they are under contract with the power companies.

In relation to building characteristics, most households are old houses of less than 90 $\mathrm{m}^{2}\left(51 \%\right.$ were built prior to 1970 , and $41 \%$ are smaller than $\left.60 \mathrm{~m}^{2}\right)$. The tenure status is predominantly rental $(68.4 \%)$, and the households are located in blocks of flats (80\%). With regard to living conditions, a self-reported variable indicates that than $44 \%$ of the respondents' households consider to have temperatures below $18 \mathrm{C}^{\circ}$ in winters, and a similar percentage declares to have temperatures above $28 \mathrm{C}^{\circ}$ at home in summers. To this end, more than $58 \%$ of households express dissatisfaction with these temperatures.

A study of the sample indicates that the impact of household energy supply costs (bills) and resident consumption habits do not represent a significant factor in the degree of the intensity of energy poverty in Aragon, except in specific cases.

In more than $80 \%$ of the analyzed cases, energy costs represent more than $10 \%$ of household income. This data was considered only for descriptive purposes because the energy poverty situation of households was certified by the social services. In this sense, it has to be taken into account that some households may actually be under-spending precisely because they are suffering energy poverty.

For a purely descriptive purpose, in general terms we can see how the total energy expenditure in the various provinces of the region are not equally distributed, with lower energy costs in the principal province (Zaragoza), where the largest city and the regional capital are located. The relationship with the residence location is negative when it is located in urban areas, and thus spending on energy resources is greater when the household is located in rural areas. In general terms, the households located in rural areas of the sample have greater incomes than the urban households. Finally, despite the fact that no significant 
relationship was found between the presence of children in the home and energy expenditures, as mere descriptive data, we can see that households with at least 1 child have less income.

It is demonstrated that the power supply contract under the social tariff programme (regulated rate reduced by $25 \%$ called "bono social") corresponds to a lower level of energy expenditure. Consequently, the easing of conditions to access this regulated tariff could be an advantage for those homes and a first step towards alleviating energy poverty in Spain. It is also demonstrated that city gas and oil heating systems entail greater energy costs, while butane cylinders and electric heating systems have lower costs. In short, homes located in rural areas are mostly owned by survey respondents, are larger than those located in urban areas, and have fewer facilities for heating and air conditioning systems (HVAC), which represents an increase in electrical expenditures. Nonetheless, they possess heating systems with alternative energy sources such as stoves and fireplaces, a point in favour when exploring at a local level for alternative sources of energy in the region.

At this point, it is noteworthy that the possible use of renewable sources, which are abundant in the region, was not analysed, primarily because almost all of the households studied are connected to the network and currently there is low penetration of solar thermal or photovoltaic equipment in homes with the aforementioned features where the survey respondents reside. In addition, the Spanish rules for renewables do not represent an affordable framework for these solutions and premium tariffs for micro-generation or small scale renewable heat have not been promoted to help the fuel poor.

With regard to types of social aid, it was possible to confirm that households receiving more support spend less in the energy bills, and thus, users of this type of social services 
might generally control spending more carefully, probably because of its situation of urgent necessity and the indirect control of social services.

It may be proposed, then, that there is an increased and more pressing intensity of the energy poverty phenomenon in those homes located in urban areas, where building features and available facilities, such as home appliances, have a negative impact that limits the use of alternative energy sources and possible preventive measures in terms of refurbishing their residences because they are mostly block flats and rental units because the majority of urban houses are not equipped with fireplaces and they cannot use other fuels such as biomass.

\section{Discussion}

In the region analysed as study case, there was an increase in the degree of attention paid to energy poverty during the recent years by the regional institutions, as well as by society and the media. This was principally due to the notable increase in emergency aid for energy requested by families that in 2014 increased by $90 \%$ compared to the previous year. These aids have been generally linked to housing (mainly under the Art. 47 of Spanish Constitution), without detriment to the fact that this phenomenon has to be dealt with as an index of relative poverty within the relevant problem related to absolute poverty.

At present, these subsidies received or requested by the homes affected by energy poverty in the region are different in number and magnitude and they depend on the county or the municipalities. Public administration and private entities (NGOs) that also work in these households do not have common aid criteria. Furthermore, these criteria do not correspond to the poverty rate for each household but instead to local regulations and budget availability. Additionally, there are differences in the provision of services that are ultimately unrelated to the needs associated with the level of energy poverty in the 
household or the gravity of the situation. Thus, an urgent need to unify the criteria for allocating the subsidies in the whole region was pointed out as result of this study.

Despite their heterogeneity, the emergency measures implemented in the Region to date can be considered adequate to provisionally alleviate the problem of energy poverty. However, experts interviewed during the qualitative analysis stressed that these are measures which, as the name suggests, have to be used only for urgent and unexpected situations, during a short period. Specific planning at regional level seems to be necessary in this regard to prevent household needs growing uncontrollably. The measures are justified by their urgency but if they are used indefinitely could cause an increase in the problem instead of promoting its prevention.

In this context, potential measures to be taken in the region in order to address principal needs pointed out by the study were analysed: a) to elaborate specific regional policy measures, especially concerning energy efficiency and the emergency measures management; b) to avoid electricity disconnections in the energy poverty households; c) to propose amendments to the regional or national legislation. Principal proposals regarding this subject are summarized in the following paragraphs.

As a first step, the development of administrative powers of the Regional Government in areas such as consumer, energy and social services were also analysed. In Spain, regions could regulate the protection of energy consumers and, in particular, those in energy poverty $^{3}$. In this point the possibility to regulate the electricity as an essential service could

\footnotetext{
3 By amending regional Law 16/2006 of 28 of December on the Protection and Defense of Consumers and Users of Aragon and article 5 of Law 16/2006, about consumers that can be protected (paragraph f refers to vulnerable consumers so it could be applied to households in energy poverty).
} 
be considered in those household affected by energy poverty, particularly where elderly and children resided, in order to avoid electricity disconnections ${ }^{4}$.

This analysis led to the conclusion that an interdepartmental group of experts would have to be constituted in relation to prevent regional energy poverty to propose as well specific solutions for those affected households. The accreditation by social services of households affected by energy poverty respond to this need in most cases, despite the fact that it could prove restrictive in some cases by excluding a number of households that suffer the consequences of the problem that are not recipients and/or applicants for social aid.

By conducting the field work in close collaboration with both regional social services and active NGOs in this area, it was possible to measure the extent of the phenomenon of accredited energy poverty and to observe some of the determinants in homes at the regional level. In fact, the accreditation of energy poverty makes it possible to define the intensity of the problem at a regional level, to locate households in need according to their characteristics and to plan public and private interventions.

The public grants aimed at energy refurbishment of buildings available at regional level were also discussed given the results obtained in the empirical phase. The grants offered by the Regional government yearly would have to be amended in order to apply them to specific situation of houses under energy poverty. At present their purpose is in fact raised to reduce energy consumption and improve thermal conditions of the buildings under parameters required by regulation. This means a private investment and high energy saving performance. Thus, these conditions preclude its usefulness for houses affected by energy poverty because they cannot contribute to the investments and they have reduced energy consumptions.

\footnotetext{
4 This could be achieved amending Law 16/2006 and applying article 89 of RD 1955/2000.
} 


\section{Conclusion and Policy implications}

Spain has not been excluded from the energy poverty phenomenon and various national institutions have taken steps mainly to assess the problem at the local, regional, and national level and define which actions ought to be taken and measures adopted. In this country, a sphere of powers allows regions (called "Autonomous Communities") to regulate specific measures related to energy poverty through the establishment of regional policies ${ }^{5}$. Exclusive administrative powers in the field of consumption, training and education or the regulation of authorizations for energy facilities and energy planning at regional level correspond to the regions (called "Autonomous Communities"). Social action, including the management, organization and development of a public system of social services, is regulated under the jurisdiction of shared competencies as well.

Indeed, the development of regional strategies in the energy field intended to restrict the exclusion of homes affected by energy poverty is deeply impacted today by the multilevel governance aspects and the limitations in the public budget available for this problem.

In this context, this study has sought to achieve a first approximation of the characteristics that lead to energy poverty in a Spanish region, Aragón, where the public energy poverty strategy occur is affected by 2 essential factors: a deep economic crisis and the fact that we are addressing a problem within a general framework of poverty.

The Regional Government of Aragon, within its powers, monitors at present the distribution and commercialization utilities concerning the customer's rights, paying special attention to the rights of vulnerable consumers. Thus, the agreements signed between

\footnotetext{
${ }^{5}$ Under the articles 140 and 149.1 of Spanish Constitution
} 
utilities and local administrations in order to avoid disconnection in these households can be considered an adequate solution.

In any case, regions must identify the households that are the most vulnerable to the problem and their main features to take concrete steps which are preventive and/or palliative in nature, suitable for every type of home, and considered on the basis of the index of energy poverty. However, such aid is allotted according to stipulated amounts and local budget availability.

That is why it is necessary for the responsible authorities to have an understanding of the determining factors of the energy poverty and its intensity in each case to implement a series of specific measures.

The results obtained through the analysis can be applied to the decision-making of the regional government to implement palliative measures, while long-term preventive measures are not being adopted because they require higher budgetary allocation.

In this context, domestic consumers affected by energy poverty, in particular, those living on a limited income but with required energy expenditures, should benefit from special pricing schemes to avoid the negative impact of the crisis because these homes suffer the negative consequences of this phenomenon on a daily basis.

National practices of the member countries concerning vulnerable consumers under the EU Directives could affect the number of consumers living in energy poverty because the price of essential energy products only represents a percentage of the final bill; numerous taxes, levies, supports for diversification and energy security, etc., which depend on national energy policy, must be added. 

prevention of electricity disconnections in these households.

Nevertheless, any proposals coming from the regional government led to the modification of national regulation in the energy field have no binding character. Regional proposals in this case were addressed to the regulatory changes concerning the application of specific inclusion of those people living in energy poverty, because they have to have access to this social tariff whatever the circumstances. A reduction of VAT (value added tax) and other tax rates for those consumers in energy poverty could be proposed as well.

Additionally, in relation to performance, regional institutions should provide transparent information to consumers and education, efficient control management, and specific local measures, among others, particularly in publicly owned housing, even if only in the local sphere.

For this reason, the main objectives of this work have been achieved through the development of a methodology for an observational quantitative analysis and the description of energy poverty in households through a regional case study.

It is important to note that this study is only a description of a state or moment in time in a Region, and cannot capture the dynamic interrelationships among the different factors. The use of more complex statistical techniques that enable the study of the type and the direction of the relationship between variables remains a future line of inquiry, especially because the methodology used in the present only allowed for studying linear relationships.

The limitations of the study in terms of geographic scope and the breadth of the variables tested can open new lines of future research aimed characterising and modelling the main determinants of the energy poverty index in European households and to establish 
1 correlations between these determinants and the palliative or preventive measures to be applied. 
This work has been possible thanks to funding from and the initiative of the Aragon Government - Department of Industry and Innovation - General Directorate for Energy and Mines. In particular, we would like to thank the Director General of Mines and Energy, Marina Sevilla Tello, and the Head of the Service of Energy Planning, Sergio Breto Asensio, for their collaboration and contributions to this study.

The field work for this study was conducted thanks to the active collaboration of the Social Services of the municipalities and counties of Aragon, the Diocesan Caritas and Spanish Red Cross staff, and the support provided by more than 100 Aragonese entities. 


\section{References}

Baker, W., Starling, G., Gordon, D., 2003. Predicting Fuel Poverty at the Local Level: Final Report on the Development of the Fuel Poverty Indicator. Centre for Sustainable Energy, Bristol.

Bergasse, E., Paczynski, W., Dabrowski, M., Dewulf, L., 2013. The relationship between energy and economic and socio- economic development in the southern and eastern mediterranean. CASE-Center for Social and Economic Research on behalf of CASE Network EAN 9788371785818, 2013.

BERR - Department for Business Entreprise \& Regulatory Reform. 2001. The UK Fuel Poverty Strategy. Government of United Kingdom. Department of Energy and Climate Change 2001.

Blázquez, L., Boogen, N., Filippini, M., 2013. Residential electricity demand in Spain: New empirical evidence using aggregate data. Energy Economics 36 ,2013. 648-657

Boardman, B., 1991. Fuel Poverty: From Cold Homes to Affordable Warmth. Belhaven Press, London.

Boardman, B. 2012. Fuel poverty synthesis: Lessons learnt, actions needed. Energy Policy $49,2012.143-148$.

Bouzarovski, S., 2012., Energy poverty policies in the EU: a critical perspective. Energy Policy, Volume 49, October 2012, Pages 76-82

Bouzarovski, S., Petrova, S., Tirado-Herrero, S. (2014). From Fuel Poverty to Energy Vulnerability: The Importance of Services, Needs and Practices. SPRU Science Policy Research Unit. University of Sussex. Working Paper Series SWPS 2014-25. 2014 https://www.sussex.ac.uk/webteam/gateway/file.php?name=2014-25-swpsbouzarovskipetrovatirado.pdf\&site=25. Assessed in May 2015

Brunner, K.M., Spitzer, M., Christanell, A., 2012. Experiencing fuel poverty. Coping strategies of low-income households in Vienna/Austria. Energy Policy, 49 ,2012. 53-59

CESE. Comité Económico y Social Europeo, 2013. Por una acción europea coordinada para prevenir y combatir la pobreza energética. Dictamen del CESE. TEN/516 Bruselas, 18 de 
septiembre de 2013. Disponible en http://www.prefieres.es/images/articulos/Biblioteca38.pdf , (Assessed in September 2014 .)

Chaudhuri, S \& Ravallion, M., 1994. "How well do static welfare indicators identify the chronically por?" Journal of Public Economics. Vol 53 ,3 367-394. http://ec.europa.eu/energy/gas_electricity/doc/forum_citizen_energy/20140106_vulnerabl e_consumer_report.pdf . (Assessed in September 2014)

Cormack, D., Friel, K., Grainger, S., Millen, D., Robinson, A., 2004 .Fuel Poverty in Scotland: Further Analysis of the Scottish House Condition Survey 2002. Communities Scotland and Scottish Executive, Edinburgh.

Devaliere, I., 2010. Identification des processus de precarisation energetique des menages et analyse des modes d'intervention. CSTB. Paris.

Espada-Nicolás., R., Casas Abajo, D., López Fernández, J.L., 2012. "Soluciones de rehabilitación energética. Oportunidad de desarrollo económico y empleo verde en Extremadura”. Asociación de Ciencias Ambientales, ACA, Madrid.

EU-SILC 2003. European Union Statistics on Income and Living Conditions - 2003 http://epp.eurostat.ec.europa.eu/portal/page/portal/microdata/eu_silc .

Euroean Commission. (2013) Study on promoting multi-level governance in support of Europe 2020. Inception Report. Regional and Urban Policy. Luxembourg. European Union 2103.

Fahmy, N., Gordon,D., Patsios, D. (2011). Predicting fuel poverty at a small-area level in England. Energy Policy 39 (2011) 4370-4377

Grevisse, F. \& Brynart, M., (2011). "Energy Poverty In Europe: Towards a more global understanding". European Council for an Energy Efficient Economy 2011 Summer Study. http://proceedings.eceee.org/visabstrakt.php?event=1\&doc=2-478-11, (Assessed in August 2014).

Healy, J.D., Clinch J.P., (2002). Fuel poverty, thermal comfort and occupancy: results of a national household-survey in Ireland. Applied Energy 73, 2002 . 329-343

Healy, J.D., Clinch J.P., (2002). Fuel poverty in Europe: a cross-country analysis using a new composite measurement. Environmental Studies Research Series. Working Papers. University College Dublin. ESRS 02/04 . 
http://www.ucd.ie/gpep/research/archivedworkingpapers/2002/02-04.pdf (Assessed in May 2015)

Heindl, P. (2013) : Measuring fuel poverty: General considerations and application to German household data, ZEW Discussion Papers, No. 13-046

Hills, J., 2012. Getting the measure of fuel poverty. Final Report of the Fuel Poverty Review., CASE report 72. Centre for Analysis of Social Exclusion. The London School of Economics and Political Science., London, UK.

Howden-Chapman, P., Viggers, H., Chapman, R., O'Sullivan, K., Telfar Barnard, L., Lloyd, B., ,2012 .. Tackling cold housing and fuel poverty in New Zealand: A review of policies, research, and health impacts. Energy Policy, Volume 49., 2012. 134-142

IAEST. 2013. Instituto Aragonés de Estadística. Encuesta Condiciones de Vida. Años 2004 a 2013. http://www.aragon.es/DepartamentosOrganismosPublicos/Organismos/InstitutoAragones Estadistica/pcaxis/ci.Aplicacion_axis_Encuesta_Condiciones_Vida_Definitivos.detalleD epartamento

International Energy Agency. 2011. Energy for all. Financing access for the poor. http://www.iea.org/papers/2011/weo2011_energy_for_all.pdf (Accessed in June 2014).

Liddel, C., Morris, C., McKenziie S.J.P., \& Rae, G., 2012. Measuring and monitoring fuel poverty in the UK: National and regional perspectives. Energy Policy. 49. 27-32.

Li K, Lloyd B, Liang X-J \& Wei Y-M. 2014. Energy poor or fuel poor: What are the differences?. Energy Policy, 68, p.p. 476-481.

Mirza, B., Szirmai, A., 2010. Towards a New Measurement of Energy Poverty: A CrossCommunity Analysis of Rural Pakistan. UNU-MERIT Working Paper Series 024, United Nations University, Maastricht Economic and social Research and Training Centre on Innovation and Technology.

Moore, R. 2012. Definitions of fuel poverty: Implications for policy. Energy Poverty. 49. 19-26.

Morrison, C., Shortt, N., 2008. Fuel poverty in Scotland: Refining spatial resolution in the Scottish Fuel Poverty Indicator using a GIS-based multiple risk index. Health \& Place 14, 2008 . 702-717 
Muthén, L.K., and B.O. Muthén. 1998-2012. Mplus User's Guide. Fifth Edition. Los Angeles, CA: Muthén and Muthén.

Muthen B.O. \& Satorra, A. 1995. Complex sample data in structural equation modeling, Sociological Methodology, 25, 267-316.

Nussbaumer, P., Bazilian, M., Modi, V., 2012. Measuring energy poverty: Focusing on what matters. Renewable and Sustainable Energy Reviews 16, 2012 . 231- 243

Pachauri, S., Spreng, D., 2011. Measuring and monitoring energy poverty. Energy Policy, 39, 2011. 7497-7504

Practical Action, 2013. "Poor people's energy outlook 2013. Energy for community services". Practical Action Publishing Ltd The Schumacher Centre. United Kingdom 2013. ISBN 9781780447896 Ebook. http://practicalaction.org/ppeo2013 (Assessed in August 2014).

Rab,S., Howell, N., Dahlaw, K., 2011. The EU's Third Energy Package: Reforms Kick-In but Member State Implementation Lags Behind.Energy newsletter King\&Spalding. August 2011. http://www.kslaw.com/library/newsletters/EnergyNewsletter/2011/August/article1.html , (Assessed in August 2014).

Rivera, P. \& Satorra, A. (2002). Analysing group differences: a comparison of SEM approaches, in Marcoulides, G. and Moustaki, I. (Eds.), Latent Variable and Latent Structure Models (86-.104), Lawrence Erlbaum Associates, Inc., Publishers, Mahwah, U.S,

Roberts, S., 2008. Energy, equity and the future of the fuel por. Energy Policy 36, 2008. $4471-4474$

Rudge, J., 2001. Developing a methodology to evaluate the outcome of investment in affordable warmth. Report to the Eaga Charitable Trust, Keswick, ISBN 1901616053.

Rudge, J., 2012. Coal fires, fresh air and the hardy British: A historical view of domestic energy efficiency and thermal comfort in Britain. Energy Policy. Volume 49, Pages 611 . 
Satorra, A. (2003). Power of chi-square Goodness-of-fit test in structural equation models: the case of non-normal data (p. 57-68) en New Developments of Psychometrics. Tokyo: Springer Verlag.

Satorra, A., \& Bentler, P.M. (1994). Corrections to test statistics and Standard errors in covariance structure analysis. In A. von Eye \& C.C. Clogg (Eds.): Latent variables analysis: Applications for developmental research (399-419). Thousand Oaks, CA: Sage.

Santamouris, M., Paravantis, J.A., Founda, D., Kolokotsa, D., Michalakakou, G., Papadopoulos, G.M., 2012. Fuel poverty and the financial crisis: a household survey in Greece. http://www.aivc.org/sites/default/files/50.1366923297.full_.pdf, (Assessed in September 2014).

Síndic de Greuges de Catalunya, 2013. "Informe sobre la Pobreza Energética en Cataluña. Octubre 2013". http://www.sindic.cat/site/unitFiles/3530/Informe\%20pobreza\%20energetica\%20complet o.pdf, assessed May 2014 .

Sovacool, B.K., Cooper, C., Bazilian, M., Johnson, K., Zoppo, K., Clarke, S., Eidsness, J., Crafton, M., Velumail, T., Raz, H.A., 2012.What moves and works: Broadening the consideration of energy poverty. Energy Policy 42, 2012. 715-719

Thomson, H., Snell, C., 2013. "Energy Poverty in the EU". The University of York. Department of social Policy and Social Work. 2013.

http://fuelpoverty.eu/wp-content/uploads/2013/06/Final-energy-poverty-policy-brief-EUEnergy-Week-13.pdf (accessed in August 2014).

Tirado-Herrero., S. López Fernández, J.L., Martín García, P., 2012. "Pobreza energética en España, Potencial de generación de empleo derivado de la rehabilitación energética de viviendas.” Asociación de Ciencias Ambientales, ACA., Madrid.

Tirado-Herrero., S., Jiménez Meneses, L., López Fernández, J.L., Martín García, J., 2014. "Pobreza energética en España. Análisis de tendencias." Asociación de Ciencias Ambientales, ACA, Madrid.

Tirado-Herrero, S., Bouzarovski, S. (2014) Energy Transitions and Regional Inequalities in Energy Poverty Trends: Exploring the EU Energy Divide (December 11, 2014). USAEE 

http://dx.doi.org/10.2139/ssrn.2537067 
Table(s)

Table 1

\begin{tabular}{|c|c|c|c|c|c|}
\cline { 2 - 6 } \multicolumn{1}{c|}{} & $\mathbf{2 0 1 1}$ & $\mathbf{2 0 1 2}$ & $\mathbf{2 0 1 3}$ & $\mathbf{2 0 1 4}$ & $\mathbf{2 0 1 5}$ (estimated) \\
\hline Total number of households & 542 & 716 & 1301 & 2471 & 3088 \\
\hline
\end{tabular}


Table 2

\begin{tabular}{|c|c|c|c|c|c|}
\cline { 2 - 6 } \multicolumn{1}{c|}{} & $\mathbf{2 0 1 1}$ & $\mathbf{2 0 1 2}$ & $\mathbf{2 0 1 3}$ & $\mathbf{2 0 1 4}$ & $\mathbf{2 0 1 5}$ (estimated) \\
\hline $\begin{array}{c}\text { Local Administrations } \\
\text { (Euro) }\end{array}$ & $144,492.01$ & $144,558.98$ & $217,909.45$ & $382,049.91$ & $447,950.09$ \\
\hline NGOs (Euro) & NA & NA & $428,114.66$ & $837,235.10$ & $981,650.62$ \\
\hline Total (Euro) & $144,492.01$ & $144,558.98$ & $646,024.11$ & $1,219,285.01$ & $1,429,600.71$ \\
\hline
\end{tabular}


Table 3

\begin{tabular}{|c|c|c|c|}
\hline VARIABLES & VALUE LABELS & $\%$ & Cumulative\% \\
\hline \multirow[t]{3}{*}{ PROVINCE } & Huesca & 14.8 & \\
\hline & Teruel & 13.0 & \\
\hline & Zaragoza & 72.2 & \\
\hline \multirow[t]{2}{*}{ RESIDENCE } & Rural & 21.6 & \\
\hline & Urban & 78.4 & \\
\hline \multirow[t]{2}{*}{ NACIONALITY } & Spanish & 54.8 & \\
\hline & Others & 45.2 & \\
\hline \multirow{4}{*}{ HOUSEHOLD INCOME } & Less than $9,000 € /$ year & 79.7 & 79.7 \\
\hline & From 9,000 to $14,000 € /$ year & 15.8 & 95.4 \\
\hline & From 14,001 to $19,000 € /$ year & 2.3 & 97.7 \\
\hline & From 19,001 to $25,000 € /$ year & 2.3 & 100.0 \\
\hline \multirow{4}{*}{ HOUSEHOLD STRUCTURE } & 1 Member & 10.9 & 10.9 \\
\hline & 2-3 Members & 32.0 & 42.9 \\
\hline & 4-5 Members & 43.9 & 86.8 \\
\hline & More than 5 Members & 13.2 & 100.0 \\
\hline \multirow[t]{5}{*}{ CHILDREN IN THE HOUSEHOLD } & No Childrens & 24.1 & 24.1 \\
\hline & 1 Child & 21.8 & 45.9 \\
\hline & 2 Childrens & 27.8 & 73.7 \\
\hline & 3 Childrens & 16.1 & 89.8 \\
\hline & More than 3 Childrens & 10.2 & 100.0 \\
\hline \multirow[t]{3}{*}{ ACTIVE WORKRES } & All members unemployed & 71.2 & 71.2 \\
\hline & At least one member & 24.9 & 96.1 \\
\hline & Two or more members & 3.9 & 100.0 \\
\hline \multirow{3}{*}{ HOME OWNERSHIP } & Owner & 25.2 & \\
\hline & Rent & 60.8 & \\
\hline & Other & 14.0 & \\
\hline \multirow{6}{*}{$\begin{array}{l}\text { YEAR OF CONSTRUCTION OF THE } \\
\text { BUILDING }\end{array}$} & Before 1970 & 49.6 & 49.6 \\
\hline & From 1970 to 1979 & 16.8 & 66.4 \\
\hline & From 1980 to 1989 & 12.0 & 78.4 \\
\hline & From 1990 to1999 & 9.8 & 88.2 \\
\hline & From 2000 to 2010 & 10.0 & 98.3 \\
\hline & After 2010 & 1.7 & 100.0 \\
\hline \multirow[t]{2}{*}{ HOUSING TYPE } & Housing in Tower Block & 81.5 & \\
\hline & Houses & 18.5 & \\
\hline \multirow{4}{*}{ TAMAÑO DE VIVIENDA $\left(\mathbf{m}^{2}\right)$} & Less than $60 \mathrm{~m}^{2}$ & 39.9 & 39.9 \\
\hline & From 60 to $75 \mathrm{~m}^{2}$ & 25.3 & 65.2 \\
\hline & From 76 to $90 \mathrm{~m}^{2}$ & 17.1 & 82.4 \\
\hline & More than $91 \mathrm{~m}^{2}$ & 17.6 & 100.0 \\
\hline \multirow[t]{4}{*}{ NUMBER OF ROOMS } & Less than 4 & 16.2 & 16.2 \\
\hline & 5 Rooms & & \\
\hline & 6 Rooms & & \\
\hline & More than 6 & & \\
\hline \multirow{3}{*}{$\begin{array}{l}\text { TYPE OF CONTRACT } \\
\text { (ELECTRICITY) }\end{array}$} & Voluntary price small cons. (VPSC) & 46.3 & \\
\hline & "Free Market" & 35.9 & \\
\hline & "Social Tariff" & 17.8 & \\
\hline \multirow[t]{4}{*}{ POTENCIA } & Less than $3 \mathrm{~kW}$ & 58.7 & 58.7 \\
\hline & From 3 to $4 \mathrm{~kW}$ & 17.9 & 76.7 \\
\hline & From 4 to $5 \mathrm{~kW}$ & 10.5 & 87.2 \\
\hline & More than $5 \mathrm{~kW}$ & 12.8 & 100.0 \\
\hline \multirow[t]{3}{*}{ HOT WATER SYSTEM } & Individual & 90.5 & \\
\hline & Centralized & 6.9 & \\
\hline & Solar collectors & 2.6 & \\
\hline \multirow[t]{2}{*}{ HOT WATER HEATING SYSTEM } & No & 39.6 & \\
\hline & Yes & 60.4 & \\
\hline \multirow[t]{2}{*}{ HEATING SYSTEM } & Individual & 80.8 & \\
\hline & Central & 19.2 & \\
\hline \multirow{2}{*}{$\begin{array}{l}\text { ALTERNATIVE HEATING SYSTEM } \\
\text { (No electricty and no gas) }\end{array}$} & No & 65.9 & \\
\hline & $\mathrm{Si}$ & 34.1 & \\
\hline
\end{tabular}


TABLE 4.

\begin{tabular}{|c|c|c|}
\hline & ENERGY COSTS & $\begin{array}{c}\text { \% ENERGY EXPENDITURES ON } \\
\text { TOT. HOUSEHOLDS INCOME }\end{array}$ \\
\hline \multicolumn{3}{|l|}{ PROVINCE } \\
\hline HUESCA* & $.096^{* *}$ & .021 \\
\hline TERUEL* & $.162 * * *$ & -.026 \\
\hline ZARAGOZA* & $-.198 * * *$ & .003 \\
\hline \multicolumn{3}{|l|}{ RESIDENCE } \\
\hline URBAN * & $-.081 * *$ & $.084 * *$ \\
\hline \multicolumn{3}{|l|}{ NATIONALITY } \\
\hline SPANISH* & .054 & $-.069 *$ \\
\hline \multicolumn{3}{|l|}{ HOUSEHOLD INCOME } \\
\hline ANNUAL INCOME & $.477 * * *$ & -- \\
\hline INCOME HIGHER THAN 9,000 € & $.434 * * *$ & -- \\
\hline \multicolumn{3}{|l|}{ HOUSEHOLD STRUCTURE } \\
\hline HOUSEHOLD SIZE & .019 & .039 \\
\hline NUMBER OF ADULTS & $.075^{*}$ & -.031 \\
\hline CHILDREN IN THE HOUSEHOLD * & -.011 & $.078 *$ \\
\hline NUMBER OF CHILDREN & -.023 & .065 \\
\hline \multicolumn{3}{|l|}{ LABOUR STATUS } \\
\hline ALL MEMBERS UNEMPLOYED * & $-.300 * * *$ & -.008 \\
\hline NUMBER OF ACTIVE MEMBERS & $.301 * * *$ & -.047 \\
\hline NUMBER OF UNEMPLOYED MEMBERS & $-.115^{* * *}$ & .000 \\
\hline \multicolumn{3}{|l|}{ HOME OWNERSHIP } \\
\hline OWNER & $.101 * *$ & $-.081 * *$ \\
\hline RENT & $-.122 * * *$ & .025 \\
\hline OTHER & .044 & .066 \\
\hline \multicolumn{3}{|l|}{ CHARACTERISTICS OF THE HOUSING } \\
\hline CONSTRUCTION AFTER 1970 & $.114 * * *$ & .035 \\
\hline YEAR OF CONSTRUCTION & $.195^{* * *}$ & .063 \\
\hline HOUSING IN TOWER BLOCK * & .057 & -.032 \\
\hline SURFACE AREA OF THE HOUSING (m2) & $.174 * * *$ & -.022 \\
\hline NUMBER OF ROOMS & $.195 * * *$ & -.009 \\
\hline \multicolumn{3}{|l|}{ CHARACTERISTICS OF SUPPLY } \\
\hline UNKNOWN TYPE OF CONTRACT * & $-.122 * * *$ & -.032 \\
\hline UNAWARE OF POWER * & $-.193 * * *$ & -.064 \\
\hline UNAWARE OF CONTRACT AND POWER * & $-.176 * * *$ & -.054 \\
\hline KILOWATTS CONTRACTED (kW) & $.207 * * *$ & .049 \\
\hline TYPE OF CONTRACT -VOLUNTARY PRICE (VPSC) & $.120^{* * *}$ & $.103 * *$ \\
\hline TYPE OF CONTRACT- FREE MARKET * & $.103 * *$ & -.006 \\
\hline CONTRACT TYPE-SOCIAL TARIFF * & $-.103 * *$ & $-.089 * *$ \\
\hline \multicolumn{3}{|l|}{ HEATING SYSTEM } \\
\hline ELECTRIC & $-.188 * * *$ & $-.156 * * *$ \\
\hline CITY GAS & $.259 * * *$ & $.244 * * *$ \\
\hline OIL & $.174 * * *$ & $.067^{*}$ \\
\hline CYLINDER & -.051 & .000 \\
\hline NONE & $-.174 * * *$ & $-.129 * * *$ \\
\hline \multicolumn{3}{|l|}{ HOT WATER EQUIPMENT } \\
\hline INDIVIDUAL & $-.150 * * *$ & $-.211 * * *$ \\
\hline CENTRALIZED & $.192 * * *$ & $.234 * * *$ \\
\hline SOLAR COLLECTORS & -.029 & .018 \\
\hline \multicolumn{3}{|l|}{ LIVING CONDITIONS } \\
\hline ELECTRICITY DISCONNECTIONS* & -.020 & $.075^{*}$ \\
\hline TEMPERATURE IN WINTER & .367 *** & $.228 * * *$ \\
\hline TEMPERATURE IN SUMMER & $-.167 * * *$ & .001 \\
\hline TEMPERATURE SATISFACTION* & $.161^{* * * *}$ & -.013 \\
\hline HEATING SYSTEM $*$ & $.302 * * *$ & 213 \\
\hline COOLING SYSTEM $*$ & $.093 * *$ & .049 \\
\hline \multicolumn{3}{|l|}{ SITUATION } \\
\hline NUMBER OF SUBSIDIES FOR ENERGY & $-.071 *$ & .039 \\
\hline SOCIAL SERVICES AID * & $-.088 * *$ & .074 \\
\hline NGOS AID* & $-.105 * * *$ & -.022 \\
\hline FAMILY AID FRIENDS * & .031 & .036 \\
\hline
\end{tabular}

